\title{
Analisis Faktor Penyebab Penyakit $D B D$ di Jawa Tengah Menggunakan Regresi Binomial Negatif
}

\author{
Edy Widodo ${ }^{1}$, Putri Meliana Ariani ${ }^{2}$ \\ Universitas Islam Indonesia ${ }^{1,2}$ \\ edywidodo.uii.ac.id ${ }^{1}, 14611257 @ s t u d e n t s . u i i . a c . i d^{2}$
}

\begin{abstract}
ABSTRAK
Latar Belakang: Dalam analisis regresi Poisson, variabel terikat harus memenuhi asumsi yaitu nilai variansi sama dengan rata-ratanya. Pada kenyataannya yang terjadi ketika melakukan analisis adalah variansi dari variabel terikatnya lebih besar daripada rata-ratanya yang disebut dengan terjadinya kasus overdispersi. Tujuan: Untuk memilih model terbaik yang digunakan untuk memodelkan kasus terjadinya pasien yang menderita $D B D$ di Jawa Tengah tahun 2016.

Metode: Metode yang digunakan yaitu Analisis Deskriptif untuk mengetahui gambaran umum data, regresi Poisson yang digunakan untuk data diskrit berupa bilangan cacah dan regresi Binomial negatif sebagai alternatif dari data overdispersi.

Hasil: Hasil analisis menunjukkan bahwa model terbaik yaitu regresi Binomial Negatif dibandingkan dengan regresi Poisson.

Kesimpulan: Data jumlah penderita DBD tahun 2016 di Jawa Tengah yang terdapat overdispersi terjadi pada penarikan kesimpulan uji signifikansi parameter.

Kata kunci: overdispersi; regresi binomial negatif; regresi poisson
\end{abstract}

\begin{abstract}
Background: In the Poisson regression analysis, the dependent variable must satisfy the assumption that the variance value is equal to the mean. In fact, what happens when doing the analysis is the variance of the dependent variable is greater than the average called the occurance of cases of overdispersion.

Objective: To choose the best model the case of dengue fever case in Central Java Year 2016.

Methods: The method used is Descriptive Analysis to know the general description of data, Poisson regression used for discrete data in the form of count and Binomial negative regression as an alternative to overdispersion data.
\end{abstract}

Results: The results of the analysis show that the best model is binomial negative regression compare with Poisson regression.

Conclusion: The application of Poisson regression and Binomial Negative regression to data on the number of DHF cases in Central Java in 2016 containing overdispersion occured in the withdrawal of conclusions of the parameter significance test.

Keywords: overdispersion; poisson regression; negative binomial regression 


\section{PENDAHULUAN}

Tinggi nya curah hujan dan kelembaban di Indonesia merupakan salah satu faktor penyebab berkembang nya sumber penyakit, salah satunya penyakit DBD. DBD merupakan penyakit tular vektor yang disebabkan oleh virus dengue. Virus DBD terdiri atas 4 serotipe yakni DEN-1, DEN-2, DEN-3 dan DEN-4 yang mana secara genetik tidak terdapat hubungan antara serotype 1 dengan yang lain (Trapsilowati, 2007).

Gejala yang di alami penderita yaitu demam tinggi dan umumnya di sertai dengan nyeri pada sendi, otot dan tulang, sakit kepala, serta nyeri pada bagian belakang mata (Guerdan, 2010). Berdasarkan Kementrian Kesehatan RI (2016) jumlah penderita $D B D$ di Indonesia pada bulan Januari-Februari 2016 sebanyak 8.487 orang dengan jumlah kematian 108 orang

Penelitian ini bertujuan untuk mendapatkan model terbaik dalam menggambarkan penyakit $D B D$. Manfaat yang bisa didapatkan yaitu masyarakat bisa melakukan pencegahan awal dengan cepat karena faktor utama penyebab $D B D$ telah diketahui dari model terbaik yang didapatkan.

Penelitian yang dilakukan oleh Fatmasari (2011) mengenai Regresi Poisson dan oleh Sartika (2012) mengenai model Regresi Binomial Negatif sebagai suatu alternative analisis pada model data yang mengalami overdispersi. Dari kajian pustaka tersebut, maka peneliti ingin mencari model terbaik dari regresi Poisson dan regresi Binomial Negatif dalam mengatasi data yang mengalami kasus overdispersi di Jawa Tengah. Sepengetahuan peneliti belum pernah ada penelitian tentang Analisis faktor penyebab $D B D$ di Jawa Tengah tahun 2016 yang menggunakan model regresi Binomial Negatif dan alasan tersebut yang menjadikan penelitian ini berbeda dari penelitian sebelumnya.

\section{METODE}

Keseluruhan penduduk Provinsi Jawa Tengah yang pernah mengalami penyakit
DBDselama tahun 2016 merupakan populasi dari penelitian ini sedangkan sampel yang digunakan adalah sebagian penderita $D B D$ selama tahun 2016 yang ada di Provinsi Jawa Tengah. Penelitian ini menggunakan data sekunder yang di ambil dari Dinas Kesehatan Provinsi Jawa Tengah (data jumlah kasus) dan Badan Pusat Statistik Provinsi Jawa Tengah (jumlah penduduk). Penelitian ini terdiri dari kegiatan mengumpulkan data serta teori yang relevan terhadap permasalahan yang diteliti.

Analisis data dengan model regresi Binomial Negatif. Regresi Binomial negatif merupakan model regresi non linier yang berasal dari distribusi poisson-gamma mixture sebagai penerapan dari Generalized Linear Model (GLM). Model ini akan menggambarkan hubungan antara variabel dependen dengan variabel independent yang diteliti (Keswari et.al, 2014). Binomial negatif merupakan salah satu metode untuk mengatasi overdispersi pada regresi poisson (Pradawati et al, 2013).

\section{HASIL DAN PEMBAHASAN}

\section{A. Analisis Deskriptif}

Hal pertama yang di lakukan dalam penelitian yaitu melakukan analisis deskriptif dari variabel yang digunakan. Tabel 1. Statistik Deskriptif

\begin{tabular}{ccc}
\hline Variabel & Rata-rata & Variansi \\
\hline $\begin{array}{c}\text { Jumlah } \\
D B D \\
(Y)\end{array}$ & 462.3 & 139113 \\
$\begin{array}{c}\text { Kepadatan } \\
\text { Penduduk } \\
\left(\mathrm{X}_{1}\right)\end{array}$ & 2015.4 & 5734197 \\
$\begin{array}{c}\text { Ketinggian } \\
\text { Wilayah }\left(\mathrm{X}_{2}\right)\end{array}$ & 775.6 & 693336.5 \\
$\begin{array}{l}\text { Jumlah } \\
\text { Tenaga }\end{array}$ & 1290 & 769480.6 \\
Kesehatan \\
$\quad\left(\mathrm{X}_{3}\right)$
\end{tabular}


Terlihat bahwa nilai variansi dari variabel dependen lebih besar dari rata-rata, sehingga bisa dikatakan data Jumlah Kasus $D B D$ di Jawa Tengah mengalami kasus overdispersi.

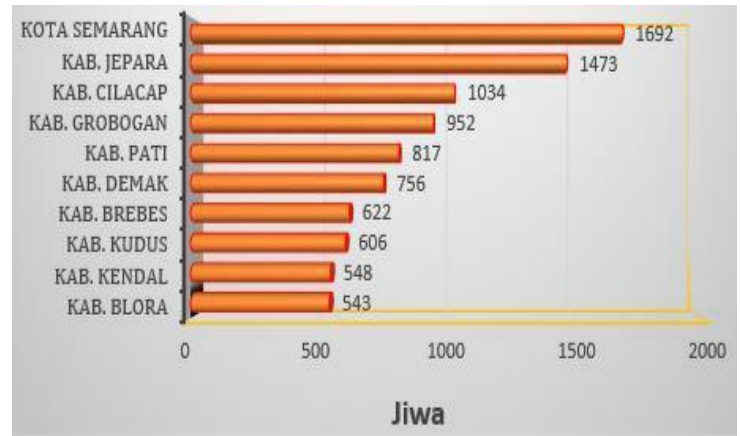

Gambar 1. Kabupaten dengan penderita penyakit $D B D$ terbanyak berdasarkan jumlah penyakit $D B D$

Gambar 1 menunjukan bahwa sepuluh kabupaten/kota dengan jumlah penderita $D B D$ tertinggi di Provinsi Jawa Tengah yang mana penderita terbanyak di Kota Semarang yakni 1692 jiwa, ketidaksadaran serta ketidakpedulian masyarakat terhadap lingkungan sekitar menyebabkan genangan-genangan air yang menumpuk sheingga jentik nyamuk sangat cepat berkembang (Prayoga, 2016). Pengaruh musim terhadap persebaran DBD masih belum begitu jelas, akan tetapi secara garis besar disebutkan bahwa jumlah penderita akan meningkat antara bulan September sampai dengan Februari yang mana bulan-bulan tersebut merupakan musim penghujan. (Harke, 2007).

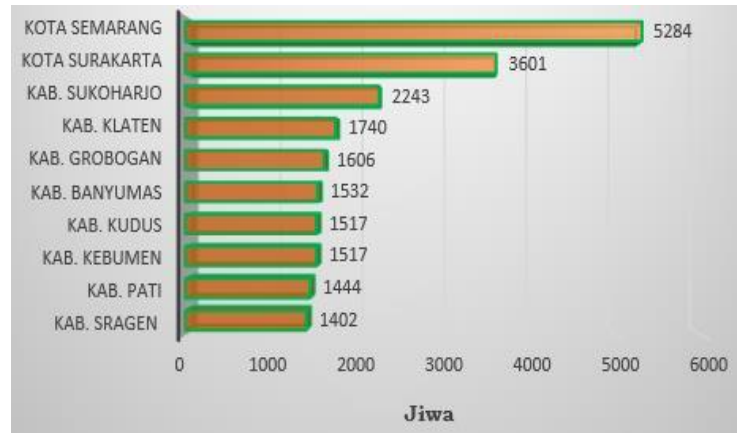

Gambar 2. Kabupaten dengan penderita penyakit $D B D$ terbanyak berdasarkan jumlah tenaga kesehatan
Meskipun angka kejadian DBD paling banyak Kota Semarang memiliki jumlah tenaga kesehatan terbanyak yaitu 5284 jiwa berdasarkan Gambar 2 di atas.

\section{B. Uji Kolmogorov-Smirnov}

Tujuan dari Uji Kolmogorov-Smirnov adalah untuk menentukan apakah data kasus $D B D$ di Provinsi Jawa Tengah tahun 2016 di 35 kabupaten/kota mengikuti distribusi Poisson atau tidak.

Tabel 2. Tampilan Uji Kolmogorov-Smirnov

\begin{tabular}{cc} 
Jumlah Sampel & Nilai Asymp. Sig \\
\hline 35 & 0.203
\end{tabular}

Analisis output untuk uji KolmogorovSmirnov adalah sebagai berikut:

(i) Hipotesis

$\mathrm{H}_{0}:($ ( ) $=0($ ( ) (Data berasal dari populasi berdistribusi Poisson)
$\mathrm{H}_{0}:$ ( ) 0 ( ) (Data bukan berasal dari populasi berdistribusi Poisson)

(ii) Tingkat Signifikansi

$=0.05$

(iii) Keputusan

Berdasarkan hasil output dari Tabel 2, diperoleh nilai Asymp.Sig $=0.203$ lebih besar dari Nilai $=0.05$, yang berarti gagal tolak $\mathrm{H}_{0}$.

(iv) Kesimpulan

Dapat disimpulkan bahwa variabel terikat yakni kasus DBD berasal dari populasi berdistribusi Poisson.

\section{Pengujian Multikolinieritas}

Uji Multikolinieritas diperlukan untuk mengetahui ada tidaknya variabel independent yang lain dalam satu model. Pengujian multikolinieritas menggunakan nilai VIF dimana nilai nilai VIF > 10 maka dikatakan mengalami multikolinieritas. Uji hipotesisnya adalah sebagai berikut:

(i) Hipotesis

$\mathrm{H}_{0}$ : Tidak terdapat hubungan antar variabel independen

$\mathrm{H}_{1}$ : Terdapat hubungan antar variabel independen

(ii) Tingkat Signifikansi

$$
=0.05
$$

(iii) Daerah Kritis

Tolak $\mathrm{H}_{0}$ jika nilai VIF $>10$

(iv) Keputusan 
Tabel 3. Keputusan Hasil Pengujian Multikolinieritas

\begin{tabular}{ccc}
\hline Variabel & VIF & Kriteria \\
\hline$\left(\mathrm{X}_{1}\right)$ & $1.609\left(^{*}\right)$ & 10 \\
$\left(\mathrm{X}_{2}\right)$ & $1.147\left(^{*}\right)$ & 10 \\
$\left(\mathrm{X}_{3}\right)$ & $1.664\left(^{*}\right)$ & 10 \\
$\left(\mathrm{X}_{4}\right)$ & $1.288\left(^{*}\right)$ & 10 \\
$\left(\mathrm{X}_{5}\right)$ & $1.076\left(^{*}\right)$ & 10 \\
\hline
\end{tabular}

Tidak terjadi multikolinieritas

(v) Kesimpulan

Menunjukkan bahwa antar variabel bebas tidak terjadi kasus multikolinieritas, sehingga layak di iikutsertakan dalam pembentukan model regresi Poisson dan regresi Binomial Negatif. Hal ini dapat dilihat dari nilai VIF yang kurang dari 10.

\section{Model Regresi Poisson}

Hasil pendugaan parameter untuk model regresi Poisson dapat di lihat pada Tabel 4. Hasil ini di peroleh menggunakan perangkat lunak $R$ 3.4.2.

Tabel 4. Nilai dugaan parameter model regresi

\begin{tabular}{ccc}
\multicolumn{3}{c}{ Poisson } \\
\hline $\mathrm{P}$ & Estimate & $\operatorname{Pr}(>|\mathrm{z}|)$ \\
& & \\
\hline & 6.739 & $<2 \mathrm{e}-16^{* * *}$ \\
$1.874 \times 10-4$ & $<2 \mathrm{e}-16^{* * *}$ \\
$1.038 \times 10-4$ & $<2 \mathrm{e}-16^{* * *}$ \\
$4.113 \times 10-4$ & $<2 \mathrm{e}-16^{* * *}$ \\
$1.474 \times 10-4$ & $<2 \mathrm{e}-16^{* * *}$ \\
$-5.180 \times 10-4$ & $<2 \mathrm{e}-16^{* * *}$ \\
\hline
\end{tabular}

Deviance: 9590.8; derajat bebas: 34; Rasio disperse: 5221,6; AIC: 493

Maka diperoleh model regresi Poisson sebagai berikut:

$\ln (\quad)=\quad 0+11+22+33+44+55$

()$=\exp (0+11+22+33+44+55)$

( ) $=\exp \left(6.739 \quad 1.874 \times 10^{4}\right.$

$1.038 \times 10^{4}+4.113 \times 10^{4}+1.474 \times 10^{3}$

Model tersebut menunjukkan bahwa setiap penambahan satu orang di suatu kabupaten/kota akan menyebabkan nilai harapan penderita $D B D$ meningkat sebesar $(6.739)=844.71559$ kali dengan asumsi peubah lain dianggap tetap. Artinya, setiap terjadi penambahan 10000 penduduk maka nilai harapan penderita DBD juga akan meningkat sebanyak 8447156 orang dengan asumsi peubah lain di anggap tetap.

\section{E. Uji Parsial Model Regresi Poisson}

Langkah berikutnya adalah uji parsial, uji ini digunakan untuk menentukan apakah secara parsial variabel-variabel independent berpengaruh terhadap variabel dependen. Sehingga digunakan uji hipotesis sebagai berikut:

(i) Hipotesis

$\mathrm{H}_{0}:=0$ (Variabel independent tidak berpengaruh terhadap variabel dependen)

$\mathrm{H}_{1}$ : Paling sedikit ada satu j dengan ${ }_{0}$ (Variabel independent berpengaruh terhadap variabel dependen)

(ii) Keputusan

Tabel 5. Uji Parsial Model Regresi Poisson

\begin{tabular}{ccc}
\hline Variabel & \multicolumn{2}{c}{ Nilai W } \\
\hline Konstanta & 3.841 & $85897.78\left(^{*}\right)$ \\
$\mathrm{X}_{1}$ & 3.841 & $3.40 \times 10_{10} \quad\left(^{*}\right)$ \\
$\mathrm{X}_{2}$ & 3.841 & $8.95 \times 1011 \quad\left(^{*}\right)$ \\
$\mathrm{X}_{3}$ & 3.841 & $\left.1.46 \times 1010{ }^{*}\right)$ \\
$\mathrm{X}_{4}$ & 3.841 & $\left.3.80 \times 106 \quad{ }^{*}\right)$ \\
$\mathrm{X}_{5}$ & 3.841 & $\left.3.40 \times 109 \quad{ }^{*}\right)$ \\
\hline
\end{tabular}

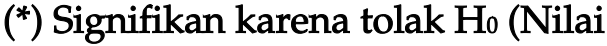

(iii) Kesimpulan

Secara parsial variabel independen berpengaruh terhadap variabel dependen sehingga model layak digunakan.

\section{F. Overdispersi}

Overdispersi pada data kasus $D B D$ di Jawa Tengah tahun 2016 ditunjukan pada Tabel 1 dimana variansi Y lebih besar dari rataan Y. Selain itu, fenomena overdispersi pada data kasus $D B D$ di Jawa Tengah dapat di lihat berdasarkan nilai Pearson Chi-Squares dan Deviance yang dibagi dengan derajat bebas bernilai lebih dari 1 .

Tabel 6. Hasil Uji Overdispersi

\begin{tabular}{cc}
\hline $\begin{array}{c}\text { Nilai } \\
\text { Deviance }\end{array}$ & $\mathrm{Db}$ \\
\hline 9591 & 34 \\
\hline
\end{tabular}

Jika nilai deviance dibagi dengan derajat bebas maka didapatkan nilai 282. Nilai yang dihasilkan melebihi angka 1, hal tersebut menunjukkan terjadi kasus overdispersi pada model regresi Poisson. Adanya overdispersi menyebabkan model regresi Poisson menjadi kurangbaik, hal ini disebabkan adanya tingkat kesalahan yang tinggi, sehingga salah satu cara yang dapat 
dilakukan untuk mengatasi adanya kasus overdispersi dalam regresi Poisson adalah dengan mengganti asumsi distribusi Poisson dengan distribusi Binomial Negatif.

\section{G. Model Regresi Binomial Negatif}

Hasil pendugaan parameter untuk model regresi Binomial Negatif dapat dilihat pada Tabel 7 berikut.

Tabel 7. Nilai dugaan parameter model regresi Binomial Negatif

\begin{tabular}{ccc}
\hline $\mathbf{P}$ & Estimate & $\operatorname{Pr}(>|\mathbf{z}|)$ \\
\hline 6.557 & $<2 \mathrm{e}-16^{* * *}$ \\
$-2.003 \times 10-4$ & $<2 \mathrm{e}-16^{* * *}$ \\
$-9.408 \times 10-5$ & $<2 \mathrm{e}-16^{* * *}$ \\
$4.548 \times 10-4$ & $<2 \mathrm{e}-16^{* * *}$ \\
$3.920 \times 10-3$ & $<2 \mathrm{e}-16^{* * *}$ \\
$-5.392 \times 10-4$ & $<2 \mathrm{e}-16^{* * *}$ \\
\hline
\end{tabular}

Deviace: 60.869; derajat bebas: 34; Rasio disperse: 37.549; AIC: 5499,2

Maka diperoleh model regresi Binomial Negatif sebagai berikut:

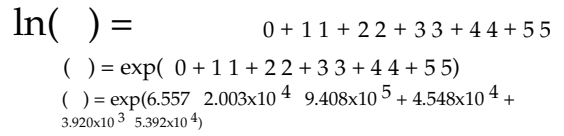

Hasil pembacaan dari Model berarti bahwa setiap penambahan satu orang pada suatu kabupaten/kota dapat menyebabkan nilai harapan penderita $D B D$ meningkat sebesar $(6.557)=704.15605$ kali dengan asumsi peubah lain di anggap tetap. Artinya, setiap penambahan 10000 penduduk akan meningkatkan nilai harapan jumlah penderita DBD sebanyak 7041561 orang dengan asumsi peubah lain di anggap tetap.

\section{H. Uji Parsial Model Regresi Binomial Negatif \\ Digunakan uji hipotesis sebagai berikut: \\ (i) Hipotesis \\ $\mathrm{H}_{0}:=0$ (Variabel independent tidak berpengaruh terhadap variabel dependen) \\ $\mathrm{H}_{1}$ : Paling sedikit ada satu $\mathrm{j}$ dengan 0 (Variabel independent \\ berpengaruh terhadap variabel \\ dependen) \\ (ii) Keputusan}

Tabel 8. Uji Parsial Model Regresi Binomial Negatif

\begin{tabular}{ccc}
\hline Variabel & & Nilai W \\
\hline Konstanta & 3.841 & $4.864\left(^{*}\right)$ \\
$\mathrm{X}_{1}$ & 3.841 & $2.81 \times 108 \quad\left(^{*}\right)$ \\
$\mathrm{X}_{2}$ & 3.841 & 0.480 \\
$\mathrm{X}_{3}$ & 3.841 & $3.68 \times 107\left(^{*}\right)$ \\
$\mathrm{X}_{4}$ & 3.841 & 0.155 \\
$\mathrm{X}_{5}$ & 3.841 & $2.42 \times 107 \quad\left({ }^{*}\right)$ \\
\hline (iii) & & \\
(iv) & (*) Signifikan karena tolak Ho (Nilai W lebih besar dari $^{\left.0.05,1^{2}\right)}$ &
\end{tabular}

(v)

(vi)Kesimpulan

Secara parsial hanya variabel Kepadatan penduduk, Jumlah tenaga kesehatan dan Jumlah curah hujan yang berpengaruh dan memiliki kontribusi terhadap variabel dependen.

\section{Kesesuaian Model Regresi Binomial Negatif}

Tujuan pemilihan model ini adalah untuk mendapatkan model terbaik dari kedua model regresi dengan perbandingan untuk mengatasi terjadinya overdispersi pada model regresi Poisson.

Tabel 9. Pemilihan Model Terbaik

\begin{tabular}{ccc}
\hline Model & Nilai AIC & Deviance/db \\
\hline RP & 5499 & 330.7 \\
RBN & 493 & 1.7 \\
\hline \multicolumn{2}{l}{ RP: Regresi Poisson } \\
RBN: Regresi Binomial Negatif
\end{tabular}

Berdasarkan Tabel 9. Diketahui bahwa nilai AIC pada model regresi Binomial Negatif lebih kecil dibandingkan dengan model regresi Poisson sehingga dapat ditarik kesimpulan bahwa model terbaik untuk data kasus $D B D$ di Jawa Tengah adalah dengan menggunakan model regresi Binomial Negatif.

\section{KESIMPULAN}

Regresi binomial negatif merupakan Model terbaik untuk menggambarkan penyebab $D B D$ di Provinsi Jawa Tengah pada tahun 2016 karena memiliki nilai AIC yang paling kecil dibandingkan regresi Poisson. 


\section{DAFTAR PUSTAKA}

Agresti, A. (2002). Categorical Data Analysis. Second Edition. New York: John Wiley and Sons, Inc.

Algifari. (2000).Penyajian Data Statistik. Kudus: Tidak Dipublikasikan.

BPS. (2014). Provinsi Jawa Tengah Dalam Angka. Jawa Tengah: BPS

BPS. (2015). Provinsi Jawa Tengah Dalam Angka. Jawa Tengah: BPS

BPS. (2016). Provinsi Jawa Tengah Dalam Angka. Jawa Tengah: BPS

Guerdan, B. R. (2010). Dengue Fever/Dengue Hemorrhagic Fever. American Journal of Clinical Medicine. 7(2). 51-53.

Herke J. O. Sigariaki. (2007). Karakteristik Pengethuan dan Sikap Ibu Terhadap Penyakit Demam Berdarah Dengue. Berita Kedokteran Masyarakat. 23(3): 148-153.

Keswari, N. M. R., Sumarjaya, I. W., Suciptawati, N. L. P. (2014). Perbandingan Regresi Binomial Negatif Dan Regresi Generalisasi Poisson Dalam Mengatasi Overdispersi. E-Jurnal Matematika. 3(3): 107-115.
Trapsilowati, W., Sulistyorani, E. (2007). Pelaksanaan Standar Pelayanan Minimal Program Pencegahan dan Pemberantasan Demam Berdarah Dengue di Dinas Kesehatan Kota Semarang. Buletin Penelitian Sistem Kesehatan. 10(4): 331-339.

Pingit. (2009). Analisis Data Kategorik. Surabaya: Jurusan Statistika ITS.

Pradawati, P. S., Sukarsa. K. G., Srinadi, I. G. A. M. (2013). Penerapan Regresi Binomial Negatif Untuk Mengatasi Overdispersi Pada Regresi Poisson. EJurnal Matematika. 2(2): 6-10.

Prayoga, Nyoman. (2016). Kota Semarang Bergerak Bersama Cegah DBD, 100\% Bebas Jentik (Online) http://www.kompasiana.com/nyoma nprayoga/kota-semarang-bergerakbersama-cegah-dbd-100-bebasjentik_573a8f28ba93731f05c055a5.html. Diakses pada 8 Februari 2018 pukul 21.49 WIB).

Walpole, R, Myers, R. (1995). Ilmu Peluang Dan Statistik Untuk Insinyur dan Ilmuwan. Bandung: ITB. 